\title{
A VÁLTOZÁSMENEDZSMENT ÉS A TULAJDONOSI SZERKEZET ÖSSZEFÜGGÉSEI
}

\author{
- EMPIRIKUS TAPASZTALATOK
}

A tanulmány 105 magyarországi szervezettel készített kérdőíves felmérés eredményeire támaszkodva vizsgálja a szervezetek változásmenedzselési magatartását a tulajdonosi struktúra (hazai vagy külföldi, magán- vagy köztulajdon, cégcsoporthoz tartozás) függvényében. Az eredmények azt mutatják, hogy e három tulajdonlási jellemző a következó esetek kivételével nem áll jelentős összefüggésben az alkalmazott változásvezetési stratégiákkal és módszerekkel. A döntóen küllföldi tulajdonban lévő szervezetek hajlamosabbnak mutatkoztak a pre- és proaktív stratégiák alkalmazására, tanácsadók bevonására, rendszereik megváltoztatására és folyamatelemzési módszerek használatára, ugyanakkor alkalmazottaik ellenálló hozzáállását jellemzőbbnek ítélték, mint a döntóen magyar tulajdonban lévők. A köztulajdon domináns aránya azzal járt együitt, hogy a jogszabály-változások és/vagy a személyi változások többször jelentek meg a változás előttt, mint a magántulajdonú szervezetek esetében, a piaci verseny erősödése, a piaci igények változása, az új technológiák pedig ritkábban. Maga a változás ezeknél a szervezeteknél ritkábban jelentett új piacra lépést és az elemzési módszerek közül ritkábban alkalmazták a tanácsadókkal folytatott csoportos megbeszéléseket. A csoporthoz tartozó szervezetek többször alkalmaztak tanácsadókat, gyakrabban vonták be óket a célok meghatározásába és csoportos megbeszélésekbe. A változás módjában, a különböző szereplők bevonásának mértékében egyik tulajdonlási jellemző alapján sem találtak a szerzók jelentős különbséget a minta elemei között.

\section{Kulcsszavak: változásmenedzsment, tulajdonosi szerkezet, magatartás}

A szervezetek vezetői gyakran említik a változások menedzselésének nehézségét, mint a versenyképesség növelésének egyik kerékkötőjét (Benn et al., 2006), mert annak ellenére, hogy számos javaslat, tanács fogalmazódik meg a változások menedzselésére vonatkozóan a változási kezdeményezések jelentôs része kudarcba fullad (Burnes, 2009). Fontos kihívás ezért e terület tökéletesebb megismerése. A témakörrel foglalkozó kutatók számos aspektusból vizsgálják a változásmenedzsment folyamatát, és alakítják ki saját elméleteiket, modelljeiket, melyek hol kiegészítik egymást, hol pedig versenyeznek egymással. A téma kutatói által legfontosabbnak tartott kérdések közé tartozik a változásokat kiváltó külső és belső tényezők elemzése, meghatározása (Senior - Swailes, 2010), illetve a változások jellemzóinek leírása (Plowman et al., 2007; Ansoff - McDonnell, 1990; Dunphy - Stace, 1993; Grundy, 1993). A sikeres változásmenedzselés szempontjából lényeges a változásokkal szembeni ellenállás okainak (Spector, 2013; Bakacsi, 2015), mértékének (Coetsee, 1999) meghatározása, az ellenállás-csökkentés módszereinek, eszközeinek számbavétele (Spector, 2013). Szintén sokan foglalkoznak a változás folyamatának elemzésével, ezzel kapcsolatos modellek alkotásával (Bakacsi, 2015; Spector, 2013; Brown, 2011).

E fóbb kutatási irányokat áttekintve fogalmazódott meg bennünk a gondolat, hogy érdemes lenne hazánkban is empirikus vizsgálatot folytatni e témakörben. Lehetóségeinket figyelembe véve a kelet-magyarországi régióra koncentráltunk. A változásmenedzselés fent említett megközelítéseit szem előtt tartva kérdőívet szerkesztettünk és ezt a Debreceni Egyetem Közgazdaság- és Gazdaságtudományi Kar hallgatóinak segítségével 2014 tavaszán 105 szervezet vezetőjével kitöltettuik.

Cikkünkben a témához szorosan kapcsolódó szakirodalom áttekintését követôen ismertetjük adatfelvételi és kutatási módszerünket, majd vizsgálati eredményeinket mutatjuk be. Bár kutatásunk nem reprezentatív, ezért általánosítható megállapítások nem fogalmazha- 
tók meg belóle, de arra alkalmas, hogy további érdekes kutatási irányokat vázoljunk fel és pontosabb képet kapjunk a mintába került szervezetek változásmenedzselési gyakorlatáról. Megfeleló arra a célra is, hogy eredményeinkre támaszkodva olyan összefüggések és mintázatok létére hívjuk fel a figyelmet, melyek nem reprezentatív mintán is nagy biztonsággal azonosíthatók (Babbie, 2012).

Mivel ugyanezen a mintán végzett kezdeti elemzéseink arra mutattak, hogy van összefüggés a változásokat kiváltó tényező́k szerepe és a tulajdonosi szerkezet egyes változóinak értékei (magán- és külföldi tulajdon aránya, cégcsoporthoz tartozás) között (Ujhelyi - Kun, 2015), ezért erre alapozva a következő kutatási kérdést fogalmazzuk meg:

Azonositható-e a felvett mintán összefüggés a szervezetek tulajdonosi szerkezete és a változások menedzselésének gyakorlata között?

A kérdés megválaszolásához - a minta nyújtotta lehetôségekből kiindulva - a tulajdonosi szerkezetet a következő három, egy-egy aspektusra koncentráló, kétértékú változóval ragadunk meg:

• döntően külföldi tulajdonú szervezet: ,igen”, ha a külföldi tulajdon aránya meghaladja az 50\%-ot, egyébként „nem”,

• döntően magántulajdonú szervezet: „igen”, ha a magántulajdon aránya meghaladja az 50\%-ot, egyébként „nem”,

- cégcsoporthoz tartozás: ,igen”, ha a cégcsoporthoz tartozást jelölte meg a válaszadó, egyébként „,nem”.

A harmadik változó eleve kétértékú formában létezett a kéróíven is, de az első kettó esetében százalékos skálát alakítottunk binárissá. Erre az egyszerúsítésre a későbbiekben bemutatott vizsgálatok elvégezhetôségének biztosítása miatt volt szükség (ezzel a csoportosítással oldottuk meg a kis elemszámok problémáját).

A „cégcsoporthoz tartozás” elnevezése kompromisszum eredménye. Bár nemcsak cégek, hanem más szervezetek is múködhetnek szervezetekből álló, szorosan együttmúködő vagy közösen irányított csoportok formájában, mégis ezt az elnevezést fogjuk használni, mert egyrészt ez szerepelt a kérdőíven (így a nem cég típusú szervezetek is erre válaszoltak), másrész pedig ez az elnevezés bevett a szakirodalomban, míg „a szervezetek csoportosulása” vagy hasonló elnevezések nem, így az utóbbiak jelentése sem lenne egyértelmú.

Szintén a meglévő adatbázis lehetőségeire alapozva a változásmenedzsment következő elemeit ragadtuk ki a vizsgálat során: változásokat kiváltó tényező́k, a változás tárgya, a változás természete, adaptációs stratégiák, változásvezetési eszközök, részvétel és ellenállás.

\section{Szakirodalmi áttekintés}

A szervezeti változások menedzselése rendkívül komplex folyamat. Ahhoz, hogy megértsük és elemezzük a változás dinamikáját és megismerjük az eredményes megvalósítás feltételeit, több szempontból is meg kell vizsgálnunk azt (Spector, 2013). Először a szervezeti változásokat kiváltó tényezőket érdemes számba venni. Ezzel kapcsolatosan általános előfeltevés, hogy a szervezetek nyílt rendszerek, így bármely változás a külső vagy belső környezetükben hatással lesz múködésükre (Senior - Swailes, 2010). A külső környezet elemzésére széles körben alkalmazott módszer a PEST-elemzés (Fülöp, 2008); más szerzők konkrét tényezőket sorolnak fel, melyek gyors és jelentós változásokra késztetik a szervezeteket. Ilyenek a fogyasztói elvárások és igények jelentôs módosulása, új technológia megjelenése, a versenytársak innovatív üzleti modelljei, módosulás a munkaerő demográfiai jellemzőiben és értékeiben, valamint új társadalmi igények és feltételek megjelenése (többek közt Spector, 2013). Robbins és Judge (2013) pedig a munkaeró sajátosságainak változását, a technológiák fejlődését, a gazdasági sokkok megjelenését, a verseny, a társadalmi trendek és a világpolitika változását tekintik a szervezeti változásokat kiváltó erốknek. A külső környezet mellett számos belső szervezeti tényező, illetve azok egymásra hatása is változásokra késztetheti a szervezeteket (Burke - Litwin, 1992). Belső, szervezeti változásokat kiváltó okokra példa a vezetô, vagy más fontos szervezeti tag személyének változása, különleges ötletek megjelenése, vagy a teljesítmény romlása, de ezeket nem lehet egyértelmúen elkülöníteni a külső kiváltó tényezőktől (Senior - Swailes, 2010).

A változások természetének, gyorsaságának, mértékének vizsgálata is számos kutatót foglalkoztat. Dunphy és Stace (1993) például négyféle változást írnak le tipológiájukban. Finomhangolású változásnak nevezik azt a folyamatot, melyben a szervezet stratégiája, struktúrája, folyamatai és az emberek közötti illeszkedést igyekeznek megteremteni. Inkrementális alkalmazkodás a változó környezethez apró lépésekben történő igazodás. Moduláris transzformáció az osztályok vagy divíziók jelentősebb, radikális átszervezése. Szervezeti transzformáció a szervezet egészét érintő radikális, forradalmi változtatás a szervezet stratégiájában, struktúrájában, vezetésében, az emberek közötti interakcióban.

A szervezeti alkalmazkodás, adaptáció három stratégia mentén valósítható meg (Ackoff, 1981; Dobák, 2008). Reaktív alkalmazkodásról beszélünk, amikor a szervezet csak a külső környezetben bekövetkezett változásokat követően, utólag, kényszerből változik. Preaktív alkalmazkodás esetén a szervezet már a várható, előre jelezhetô környezeti változásokat megelőzően lépéseket tesz, változtat. Proaktív befolyásolásnak neve- 
zik azt a stratégiát, amikor a szervezet környezetének befolyásolása, alakítása, változtatása révén igyekszik saját lehetőségeit bővíteni.

Bakacsi (2015) a változásvezetés magatartási nézőpontú folyamatát az általános problémamegoldási folyamathoz hasonlónak tekinti, de specifikus jellemzőket is kiemel. Schlesinger et al. (1992) munkája alapján három nagyobb szakaszra tagolja a változásmenedzselés folyamatát: a jelenlegi helyzet, a problémák és azok okainak feltárása, a változás megvalósításához szükséges tényezők számbavétele, a változás stratégiájának és taktikájának meghatározása.

Beer et al. (1990) a hatékony változásmegvalósítás szekvenciális modelljében az alkalmazható eszközök mellett az akciók legeredményesebb sorrendjét is meghatározzák. Véleményük szerint a változási folyamatot a közös diagnózissal kell indítani, meg kell határozni az új, stratégiailag megfelelő magatartást (szerepeket, felelősséget, kapcsolatokat), segíteni kell az alkalmazottakat ezek elsajátításában, s csak ezt követôen kerülhet sor a dolgozók értékelésére, előléptetésre, helyettesítésre, új emberek felvételére. A változási folyamat utolsó szakaszában változtatják meg a struktúrákat és rendszereket. Véleményük szerint ez a beavatkozási sorrend teszi lehetôvé, hogy az emberek fel tudnak készülni a változásokra, a részvétellel elköteleződnek a változások mellett és a struktúrák és rendszerek korai változtatása nem okoz masszív ellenállást a változási folyamat kezdeti szakaszában.

A szervezetfejlesztés tervezett, szisztematikus változási megközelítés. Hosszú távú erőfeszítéseket és programokat tartalmaz, melyek célja a szervezet túlélő-képességének javítása a problémamegoldó és megújító folyamatok változtatásán keresztül (Brown, 2011). Akciókutatásra és együttmúködésre alapozott változásmodell. Nem egyszeri esemény, ami befejeződik, amikor lezajlott a változás, hanem ismétlődő akciók sorozata, ami akár a mindennapi élet részévé is válhat, ha a szervezet filozófiájába beágyazódik ez a szemlélet (Senior - Swailes, 2010). A szervezetfejlesztési programban a külső vagy belsô specialista (practitioner) tölti be a változás ügynökének (change agent) szerepét, amely támogatja, elôsegíti (facilitate), hogy a szervezeti tagok saját maguk ismerjék fel és oldják meg problémáikat (Brown, 2011; French Bell, 1995; Senior - Swailes, 2010).

A változások sikerességét nagymértékben befolyásolja az egyének reakciója a változásokra. Ehhez kapcsolódóan Coetsee (1999) egy skálán az egyének hétféle lehetséges válaszát, attitúdjét írja le az elkötelezettségtôl az agresszív ellenállásig. Nyilvánvaló, hogy a passzivitás és ellenállás különbözó formái megnehezítik, vagy akár meg is akadályozzák a változások sikeres megvalósítását. Számos kérdést lehet megfogalmazni ezzel kapcsolatban. Miért állnak ellen az emberek a változásoknak, mik az okai az eltérô reakcióknak és hogy lehet az ellenállást elkerülni, vagy legyőzni (Spector, 2013)? Pulinka (2016) cikkében részben választ ad ezekre a kérdésekre, melyben Kübler-Ross (1988) gyászfolyamat modelljét alkalmazza a szervezeti változásokra. Véleménye szerint a változásokban érintettek valamennyien keresztülmennek a gyászfázisokon, mert minden változás veszteségekkel jár. $\mathrm{E}$ folyamat különböző szakaszaihoz illeszkedő változásmenedzsment-lépések, -eszközök alkalmazásával van esély az érintettek érzelmi reakcióinak kezelésére.

Míg a szakirodalom részletesen tárgyalja az imént bemutatott kérdésköröket, kevésbé jellemzó, hogy azok hatását vállalkozási forma, méret, cégcsoporthoz tartozás, tulajdonosi szerkezet vagy ágazat függvényében elemeznék. Szabó (2005) a versenyképesség-kutatások projekt keretében kérdőíves vizsgálati módszerrel elemzi a stratégiaalkotás folyamatát, többek között a vállalati méret és tulajdoni arány függvényében. Vizsgálja a szervezet különböző hierarchiaszintjein dolgozók, illetve tanácsadó cégek bevonását is, de nem a változásmenedzselési, hanem a stratégiaalkotási folyamatba. Balaton (2009) 11 vállalat felsőszintú vezetôivel készített interjúk segítségével, kvalitatív módszerrel elemzi az EU-csatlakozás óta bekövetkezett változásokat és azok vállalati stratégiákra gyakorolt hatását. A versenyképesség-kutatások keretében készített múhelytanulmányban kitér többek között a vállalatok külső környezetének és belső adottságainak változására, de nem a változások menedzselésével, hanem a vállalatok stratégiájában bekövetkezett változásokkal foglalkozik.

Írásunk azzal kíván hozzájárulni a szervezeti változásokkal kapcsolatos ismereteink bővítéséhez, hogy a tulajdonosi szerkezet (adataink ennek három dimenzióját tették mérhetôvé: hazai vagy külföldi tulajdonlás, magán- vagy közszféra, cégcsoporthoz tartozás) öszszefüggését vizsgálják a változásmenedzsment egyes, a fenti irodalomáttekintésben is ismertetett területeire (változásokat kiváltó tényezők, a változás tárgya, a változás természete, adaptációs stratégiák, változásvezetési eszközök, részvétel és ellenállás). Bár mintánk miatt az eredményeink közvetlenül nem általánosíthatóak, mégis lényeges hozzájárulást jelent, ha esetlegesen rámutat ilyen kapcsolatok jelenlétére, létezésére (míg ha azok elterjedtségének, erősségének általános szintjére csak reprezentatív mintán kaphatnánk is választ).

\section{Minta és módszer}

A jelen tanulmányban bemutatott elemzéseket egy 2014 tavaszán lebonyolított kérdőíves vizsgálat 105 szervezetet tartalmazó adatbázisán végeztük el. A kérdőíveket a Debreceni Egyetem gazdálkodási és menedzsmentszakos hallgatói vették fel olyan, általuk elérhető („,ké- 
nyelmi” vagy „elérhetőségi” mintavétel) szervezetek tulajdonosával, vezetőjével, vagy a változások menedzseléséért felelős HR-vezetójével, melyek jelentősebb változásokon mentek át az elmúlt öt évben, és amelyeknél az alkalmazotti átlaglétszám meghaladta az 50 fót 2012-ben vagy 2013-ban.

A mintában szereplő szervezetek 2012-ben átlagosan 790 fót foglalkoztattak (a szórás 3.474 fó, az érvényes válaszok száma 104), 2013-ban átlagosan 802 fót (a szórás 3.412 fó, $N=105$ ). 2013-as éves nettó átlagos árbevételük 3.169 millió $\mathrm{Ft}$ (a szórás 8.962 millió $\mathrm{Ft}, N$ $=97$ válaszadó volt). A szervezetek közül 63 múködött a megkérdezéskor Kft, 19 ZRt vagy NyRt, 3 szövetkezet formájában. A közszférát 14 , a civil szervezeteket 2 válaszadó képviselte, 4 pedig ,egyéb” formában múködött. 42 nyilatkozott úgy, hogy cégcsoport részeként múködik, 61 pedig úgy, hogy nem (2 válasz hiányzott). A kutatásban résztvevők jelentôs részének székhelye az Észak-Alföld régióban volt (ebből 52 Hajdú-Bihar, 22 Szabolcs-Szatmár-Bereg és 3 Jász-Nagykun-Szolnok megyébe), míg Közép-Magyarország régióban 13-nak, Eszak-Magyarországon 10-nek (8 Borsod-Abaúj-Zemplén, 2 Heves), Dél-Alföldön 2-nek (1-1 Békés és Bács-Kiskun), Közép-Dunántúlon 1-nek (Fejér megye). 1 válaszadó külföldi székhelyről nyilatkozott (Dánia), 2 esetben nem érkezett válasz.

$51 \%$, vagy afeletti hazai tulajdonban 77 szervezet volt a megkérdezéskor, legalább $51 \%$ külföldiben pedig 28. Többségében magántulajdonú 73 , többségében köztulajdonú (ez egy esetben külföldi állami tulajdont jelentett) 26 cég volt.

Nemzetgazdasági ágak szerint 6 válaszadó múködött a mezőgazdaság, erdőgazdálkodás, halászat területén, 30 az iparban (ebből 19 a feldolgozóiparban) és 67 a szolgáltatási szektorban, 2-ről pedig nem tudjuk megállapítani tevékenységi körét.

Mivel kutatási kérdésünk arra irányul, hogy milyen összefüggések fedezhetôk fel a tulajdonosi szerkezet és a változásmenedzsment között, ezért a továbbiakban olyan statisztikai eljárásokat (khí-négyzet próba, kétmintás $t$-teszt) alkalmazunk a fent leírt mintán, melyek azonosíthatják a tulajdonosi szerkezetükben különböző szervezetek esetlegesen meglévő eltéréseit a változásmenedzsment aspektusait leíró változók szerint. Nem célunk ugyanakkor ezeknek az összefüggéseknek a pontos leírása, hiszen erre a rendelkezésünkre álló minta már nem nyújt lehetőséget.

A minta kutatási kérdéseink szempontjából legfontosabb korlátai között meg kell említeni a reprezentativitás hiányát (az elérhetôségi mintavétel miatt) és azt, hogy egyes vizsgált szervezettípusok alacsony számmal kerültek az adatbázisba (pl. kizárólagosan külföldi tulajdonú cégek). Az előbbi miatt a következtetéseink csak korlátozottan általánosíthatók. Bár az egyes változók közötti összefüggésekre tett megállapítások, amelyekre jelen dolgozat is koncentrál, kevésbé érzékenyek a mintavétel torzítottságára, mint a sokasági jellemzőre vonatkozóak (lásd Babbie, 2012), és ezért az eredményeink ilyen mintán is értékesek lehetnek, a későbbiekben mégis szükséges a megerósítésük vagy reprezentatív(abb), vagy legalábbis más összetételú adatokon. Az egyes részminták alacsony számossága leginkább akkor jelent gondot, ha a kevés elem miatt valamely statisztikai módszer nem végezhetô el biztonsággal (a reprezentativitást az alacsony elemszám már nem érinti, hiszen a mintavétel módja miatt az egyébként is sérült). Az általunk alkalmazott vizsgálatokban ezért e részmintákat már nem bontjuk tovább. Minden esetben elegendő ez az elemszám ahhoz, hogy e részminták egészét összehasonlítsuk az adatbázis más részeivel (Saunders - Lewis - Thornhill, 2016), ugyanis az elemzéseinkben elóforduló legkisebb, 26-os gyakoriságú csoport $(50 \%$ feletti külföldi tulajdonban lévő szervezetek) is meghaladja az alkalmazott elemzések szempontjából kritikus határt.

Természetesen jogos aggály lehet, hogy szabad-e a részmintákat egységesnek tekinteni, azaz egyszerre csak egy tulajdonlási dimenzió alapján összevetni a minta elemeit (például a döntően hazai és döntôen külföldi tulajdonú vállalatokat összehasonlítva figyelmen kívül hagyni azok magán- vagy közszférába tartozását). Bár ezt a minta korlátai miatt nem tudtuk elkerülni (a két vagy három dimenzió együttes alkalmazása túl alacsony gyakoriságú részcsoportokhoz vezetett volna), következtetéseinkben segít, ha egyszerre vesszük figyelembe a három dimenzió szerint egyenként kialakított csoportok összevetésének eredményeit.

A külföldi tulajdonlás esetén lényeges lehet a tulajdonosok nemzetisége is, hiszen a változásvezetés módja függhet attól a nemzeti intézményrendszertől, kultúrától is, mely az anyaszervezetre közvetlenül vagy legrégebben hatással van (Viardot - Calderon-Moncloa, 2011). Sajnos ilyen adattal nem rendelkeztünk, ́́gy csak úgy vehettük ezt figyelembe az elemzés során, hogy nem vontunk le következtetést a külföldi tulajdonban lévő alanyok általában vett viselkedésére, csak a hazai és a külföldi tulajdonlás közt tapasztalt eltérésekre.

$\mathrm{Az}$ 1. táblázat azt mutatja be, hogy mely jellemzők mentén mutatkoztak különbözónek egymástól a tulajdonosi szerkezet alapján képzett részminták, vagyis a mintánkban (tehát nem általánosan) mennyire függ öszsze a tulajdonlás más demográfiai jellegú változókkal.

A mintánkban szereplő, döntően külföldi tulajdonú vállalatok az iparban nagyobb, a szolgáltatásokban alacsonyabb arányban képviseltetik magukat, mint a döntően hazaiak, tulajdonosaik inkább kerülnek ki a magánszférából és hajlamosabbak cégcsoporthoz tartozni is. A döntően magántulajdonú szervezetek jelentősen 
Leíró statisztikák a három vizsgált csoportosító változó szerint

\begin{tabular}{|c|c|c|c|c|c|c|c|}
\hline & & \multicolumn{2}{|c|}{ Döntően külföldi } & \multicolumn{2}{|c|}{ Döntően magán } & \multicolumn{2}{|c|}{ Cégcsoport tagja } \\
\hline & & igen & nem & igen & nem & igen & nem \\
\hline \multirow{4}{*}{ Átlaglétszám 2013 (fó) } & átlag & 820,89 & 794,45 & 429,85 & 1998,65 & 698,10 & 894,10 \\
\hline & szórás & 984,56 & 3948,11 & 737,69 & 6698,00 & 875,34 & 4430,54 \\
\hline & $N$ & 28 & 77 & 73 & 26 & 42 & 61 \\
\hline & $t$ & $-0,04$ & & 1,19 & & 0,28 & \\
\hline \multirow{4}{*}{$\begin{array}{l}\text { Felsőfokú végzettségúek } \\
\text { aránya } 2013(\%)\end{array}$} & átlag & 27,69 & 32,35 & 25,17 & 41,27 & 28,70 & 32,34 \\
\hline & szórás & 25,11 & 28,46 & 23,30 & 31,54 & 25,40 & 28,74 \\
\hline & $N$ & 25 & 73 & 67 & 25 & 39 & 57 \\
\hline & $t$ & 0,73 & & $2,33 * *$ & & 0,64 & \\
\hline \multirow{4}{*}{$\begin{array}{l}\text { Éves nettó árbevétel } 2013 \\
\text { (millió Ft) }\end{array}$} & átlag & 5049,91 & 2443,06 & 3855,12 & 1275,10 & 5979,22 & 1227,33 \\
\hline & szórás & 7964,27 & 9269,39 & 10286,40 & 1725,89 & 13634,43 & 1476,44 \\
\hline & $N$ & 27 & 70 & 72 & 20 & 39 & 57 \\
\hline & $t$ & $-1,29$ & & $-1,11$ & & $-2,17 * *$ & \\
\hline \multirow{4}{*}{ Gazdasági ág (db) a } & Mg. & 0 & 6 & 5 & 1 & 0 & 6 \\
\hline & Ipar & 13 & 17 & 25 & 3 & 15 & 14 \\
\hline & Szolg. & 15 & 52 & 42 & 21 & 26 & 40 \\
\hline & $\chi^{2}$ & $4,43 * *$ & & $5,11 * *$ & & $5,63^{*}$ & \\
\hline \multirow{2}{*}{ Döntően külföldi (db) } & igen & 28 & - & 25 & 1 & 26 & 2 \\
\hline & $\chi^{2}$ & - & & $9,15^{* * *}$ & & $43,19 * * *$ & \\
\hline \multirow{2}{*}{ Döntôen magán (db) } & igen & 25 & 48 & 72 & - & 35 & 37 \\
\hline & $\chi^{2}$ & $9,15^{* * *}$ & & - & - & $6,27 * *$ & \\
\hline \multirow{2}{*}{ Cégcsoport része (db) } & igen & 26 & 16 & 35 & 5 & 40 & 57 \\
\hline & $\chi^{2}$ & $43,19 * * *$ & & $6,27 * *$ & & - & - \\
\hline
\end{tabular}

a A $\chi^{2}$ próba a mezőgazdasági vállalatok alacsony száma miatt csak az ipar és szolgáltatások viszonylatában került elvégzésre.

*10\%-on szignifikáns, ${ }^{* *}$ 5\%-on szignifikáns, ${ }^{* * *} 1 \%$-on szignifikáns.

kisebb arányban foglalkoztatnak felsőfokú végzettségúeket, inkább az iparban, mintsem a szolgáltatásokban tevékenykednek, jellemzőbb köztük a külföldi tulajdon dominanciája és a cégcsoporthoz tartozás. A cégcsoporthoz tartozó cégek átlagos, éves nettó árbevétele jelentősen magasabb, illetve jellemzóbb az ilyen szervezeteknél a külföldi és a magántulajdonlás, mint a cégcsoporthoz nem kapcsolódóak esetében. Ezeket az eltéréseket jelen minta esetében figyelembe kell venni a késóbbi elemzések során, továbbá azt is, hogy ezek szerint a tulajdonlás három vizsgált dimenziója közt jelentős az átfedés. Azaz, ha például a hazai és a külföldi tulajdonlás közt mutatunk ki eltérést valamely változásmenedzselési jellemzőben, akkor ez lehet, hogy nemcsak a tulajdonos nemzetiségével, hanem annak magán- vagy közszférához tartozásával vagy a cégcsoporthoz tartozással áll kapcsolatban.

\section{Az eredmények}

A változások kiváltó okaira koncentrál az első megvizsgált kérdés ("A változásokat megelőzően tapasztalta-e az alább felsorolt jelenségeket?”). A 2. táblázat első oszlopában szereplő lehetőségek közül a válaszadók többet is megjelölhettek.

A kérdőívben említett változások mögött meghúzódó jelenségeket, kiváltó okokat az ezzel kapcsolatos szakirodalmak felhasználásával (Robbins - Judge, 2013; Spector, 2013; Senior - Swailes, 2010; Fülöp, 2008) határoztuk meg. A válaszokban minden megkérdezett kiváltó okot bejelöltünk (legkevesebb 9-szer), így megállapíthatjuk, hogy későbbi kutatások során is releváns ezekre a jelenségekre rákérdezni. Ami a válaszok gyakoriságát illeti, a megkérdezettek közül legtöbben a piaci igény változását (55 szervezet) és a piaci verseny erósödését (51 szervezet) jelölték meg, s csak 9 válaszadó tapasztalta az e-kereskedelem és internet használatának erősödését a változásokat megelőzően, azok hátterében.

A 2. táblázat fő tanulsága az lehet, hogy sem a külföldi-hazai tulajdonlás, sem a cégcsoporthoz tartozás nem jár egyuitt az esetleges változást kiváltó tényezők megjelenésének/észlelésének gyakoriságával. Az 
A változásokat megelőzóen tapasztalta-e az alább felsorolt jelenségeket?

\begin{tabular}{|c|c|c|c|c|c|c|c|}
\hline \multirow{2}{*}{ Jelenség } & \multicolumn{2}{|c|}{ Külföldi } & \multicolumn{2}{|c|}{ Magán } & \multicolumn{2}{|c|}{ Cégcsoport } & \multirow{2}{*}{ Összes } \\
\hline & nem & igen & nem & igen & nem & igen & \\
\hline $\mathrm{N}$ & 77 & 28 & 26 & 73 & 61 & 42 & 105 \\
\hline \multirow{2}{*}{ Jogszabályváltozás } & 35 & 7 & 18 & 19 & 29 & 12 & 42 \\
\hline & \multicolumn{2}{|c|}{$3,58 *$} & \multicolumn{2}{|c|}{$15,29 * * *$} & $3,74 *$ & & \\
\hline \multirow{2}{*}{ Válság } & 28 & 9 & 5 & 31 & 22 & 14 & 37 \\
\hline & 0,16 & & \multicolumn{2}{|c|}{$4,47 * *$} & 0,08 & & \\
\hline \multirow{2}{*}{ Piaci verseny erősödése } & 34 & 17 & 4 & 46 & 27 & 23 & 51 \\
\hline & 2,25 & & \multicolumn{2}{|c|}{$17,40 * * *$} & 1,10 & & \\
\hline \multirow{2}{*}{ Piaci igény változása } & 37 & 18 & 6 & 48 & 28 & 26 & 55 \\
\hline & 2,17 & & \multicolumn{2}{|c|}{$14,08 * * *$} & 2,55 & & \\
\hline \multirow{2}{*}{ Új technológiai lehetôségek felismerése } & 15 & 6 & 2 & 19 & 10 & 10 & 21 \\
\hline & 0,05 & & \multicolumn{2}{|c|}{$3,86 * *$} & 0,87 & & \\
\hline \multirow{2}{*}{ E-kereskedelem és internethasználat erôsödése } & 7 & 2 & 2 & 7 & 5 & 4 & 9 \\
\hline & - & & - & & - & & \\
\hline \multirow{2}{*}{ Szervezeti teljesítmény romlása } & 14 & 5 & 5 & 13 & 10 & 9 & 19 \\
\hline & 0,00 & & - & & 0,42 & & \\
\hline \multirow{2}{*}{ Szervezeten belüli személyi változás } & 18 & 7 & 9 & 13 & 14 & 10 & 25 \\
\hline & 0,03 & & 3,13 & & 0,01 & & \\
\hline
\end{tabular}

A cellák felső sorában a jelölések darabszáma, alattuk a $\chi^{2}$ statisztika található. Ha a próba nem végezhető el az alacsony jelölésszám miatt, azt gondolatjellel jeleztük. ${ }^{*} 10 \%$-on szignifikáns, ${ }^{* *} 5 \%$-on szignifikáns, ${ }^{* * * *} 1 \%$-on szignifikáns.

egyetlen gyengén (10\%-os szinten) szignifikáns kapcsolatot a jogszabályváltozások megjelölése jelenti az esetükben.

Több változást kiváltó jelenség is szignifikáns összefüggést mutat ugyanakkor a köz- és magántulajdon dominanciájával. A döntően magántulajdonú szervezetek ritkábban jelölték meg a jogszabályváltozást (valamint 10\%-os szignifikancia mellett a személyi változásokat), ugyanakkor gyakrabban a válságot, a piaci verseny erôsödését, a piaci igény változását, az új technológiai lehetőségek felismerését. Vagyis a változást kiváltó okokban jelentôs különbséget találtunk a magán- és a közszféra - mintánkban szereplő - szervezetei közt, de sem a domináns külföldi tulajdoni aránnyal, sem a cégcsoporthoz tartozással nem mutattak kapcsolatot.

A változás tárgyában (,Mire gyakorolt hatást a szervezetben lezajlott változás?”) 7 lehetőségből jelölhettek meg többet is. Valamennyi felsorolt tényezó kapott jelölést a válaszadóktól: egyének feladatai, szerepei, felelőssége (71), folyamatok (59), stratégia (50 jelölés), struktúra (47), rendszerek (37), szervezeti kultúra (28), technológia (17). Eredményeink arra engednek következtetni, hogy a tulajdonosi szerkezet általunk mért mutatói nincsenek összefüggésben azzal, hogy mi lesz a változás tárgya. Egyedül a rendszerek (például teljesítményértékelés, kompenzáció, információs rendszer) változását jelezték gyakrabban a külföldi tulajdonú szervezetek, de ez is csak 10\%-os szinten jelentős (a 28 dominánsan külföldi tulajdonú közül 14 (50\%), a 77 dominánsan hazai tulajdonú közül 23 (30\%) jelölte; $\chi^{2}$ $=3,65^{*}$ ) és - kisebb valószínúség mellett - a cégcsoporthoz tartozók is (a 42 cégcsoporthoz tartozóból 19 (45\%) jelölte, a 61 nem tartozóból $\left.17(28 \%) ; \chi^{2}=3,30^{*}\right)$. Vagyis mintánkban a rendszerszintú változtatás jobban jellemezte mind a külföldi tulajdonú, mind az ezzel jelentős részben átfedő cégcsoporthoz tartozó cégeket, de nem találtunk e cégek közt jelentős eltérést semmilyen egyéb változtatáshoz kapcsolódóan. A magán- és közszféra pedig semmilyen változtatásban nem mutatott különbözőséget.

A következő kérdésblokkban Dunphy és Stace (1993) tipológiája alapján kellett a változás négy típusa/ mértéke közül választaniuk a válaszadóknak (a típusok leírását lásd a szakirodalmi áttekintésben). Itt csak egy választ lehetett megjelölni. A kutatásba bevont 105 szervezet több, mint egyharmada (42) a finomhangolású változást jelölte meg jellemző szervezeti változásként, körülbelül egyötöde az inkrementális alkalmazkodást (20), és csak alig több, mint $40 \%$-uk (43 eset) jelentett valamilyen transzformációs változást. Ez nem áll összhangban Dunphy és Stace (1993) eredeti kutatásának eredményeivel, ahol a vizsgálatba bevont szervezetek 
többsége transzformációt bonyolított le. Eltérő eredményeink oka lehet a két vizsgálat eltéró mintája is.

Az egyes változási típushoz és tulajdonosi szerkezethez bejelölt alacsony elemszám miatt a modell négy kategóriáját - a hivatkozott szerzópároshoz hasonlóan - két kategóriába összevonva - a finomhangolású és az inkrementális változást kismértékú változásként, a másik kettôt nagymértékű változásként azonosítva végeztük el a tulajdonosi szerkezettel való statisztikai összevetést.

\section{A négy leírás közül melyik illik legjobban a szervezetben lezajlott változásokra?}

\begin{tabular}{lccccccc} 
Változás & \multicolumn{2}{c}{ Külföldi } & \multicolumn{3}{c}{ Magán } & \multicolumn{3}{c}{ Cégcsoport } & Ösz- \\
leírása & nem & igen & nem & igen & nem & igen & szes \\
N & 77 & 28 & 26 & 73 & 61 & 42 & 105 \\
Kismértékú & 47 & 15 & 13 & 47 & 36 & 25 & 62 \\
Nagymértékú & 30 & 13 & 13 & 26 & 25 & 17 & 43 \\
X2 & 0,47 & 1,66 & 0,00 &
\end{tabular}

A cellákban a jelölések darabszáma, alul a $\chi^{2}$ statisztika található.

A 3. táblázatban közölt eredmények arra engednek következtetni, hogy a mintában szereplő szervezetek tulajdonosi struktúrájuktól függetlenül estek át különböző mértékú változásokon (nem volt kimutatható statisztikailag szignifikáns összefüggés a tulajdonosi szerkezet egyik vizsgált dimenziójával sem). Tehát nem találtunk bizonyítékot arra, hogy a magán- vagy közszférában, hazai vagy külföldi tulajdonossal, illetve függetlenül vagy cégcsoport részeként múködő szervezetek eltérő gyakorisággal lennének alanyai kis (finomhangolású vagy inkrementális), vagy nagy (moduláris vagy szervezeti transzformáció) mértékú változásoknak.

\section{Az alkalmazkodás módját illetóen melyik meghatározás jellemzi legjobban a szervezetet?} 4. táblázat

\begin{tabular}{|c|c|c|c|c|c|c|c|}
\hline $\begin{array}{l}\text { Az alkal- } \\
\text { mazkodási } \\
\text { stratégia }\end{array}$ & $\begin{array}{r}\text { Kül } \\
\text { nem }\end{array}$ & $\begin{array}{l}\text { öldi } \\
\text { igen }\end{array}$ & $\begin{array}{r}\mathrm{Ma} \\
\text { nem }\end{array}$ & igen & $\begin{array}{l}\text { Cégc } \\
\text { nem }\end{array}$ & $\begin{array}{l}\text { soport } \\
\text { igen }\end{array}$ & Összes \\
\hline $\mathrm{N}$ & 75 & 28 & 26 & 71 & 60 & 41 & 103 \\
\hline Reaktív & 39 & 7 & 17 & 26 & 31 & 13 & 46 \\
\hline Preaktív & 22 & 12 & 3 & 29 & 19 & 15 & 34 \\
\hline Proaktív & 14 & 9 & 6 & 16 & 10 & 13 & 23 \\
\hline$\chi^{2}$ & $6,12^{* *}$ & & $851^{* *}$ & & $4,82 *$ & & \\
\hline
\end{tabular}

A cellákban a jelölések darabszáma, alul a $\chi^{2}$ statisztika található. Ha a próba nem végezhető el az alacsony jelölésszám miatt, azt gondolatjellel jeleztük. ${ }^{*} 10 \%$-on szignifikáns, ${ }^{*}$ 5\%-on szignifikáns.
A következő kérdésünkre (lásd 4. táblázat) kapott válaszokból az olvasható ki, hogy a megkérdezett szervezetek majdnem fele megítélésük szerint reaktív változáson ment keresztül, de különbség van a döntően külföldi vagy hazai tulajdonban lévő, magán- vagy köztulajdonban lévő, illetve a cégcsoporthoz tartozó vagy nem tartozó szervezetek között (bár utóbbiaknál ennek szignifikanciaszintje csak 10\%) is. A külföldi és a magántulajdonban lévők, valamint a cégcsoporttagok hajlamosabbak a pre- és kevésbé a reaktív stratégiára. A külföldi tulajdon és a cégcsoporthoz tartozás továbbá együtt járhat a proaktív stratégia magasabb valószínúségével.

A szervezetek változási programjaik megvalósítása során tanácsadókhoz fordulhatnak. A tanácsadók által betöltött szerepből következtethetünk arra, hogy milyen változásmenedzselési modellt alkalmaznak. Szervezetfejlesztés (organizational development) esetén a szervezeti tagok bevonásával, részvételével próbálják megvalósítani a változásokat, ilyenkor a tanácsadó szerepe az akciók, beavatkozások támogatása (French - Bell, 1995). Szervezettervezés (organizational design) során nem ez a helyzet. A tervező (gyakran tanácsadó) célja, hogy a szervezet adottságainak megfelelő hatékony struktúrát alkosson (Dobák, 2008). A tervezési folyamat során tehát a szakértelmén van a hangsúly.

5. táblázat

Volt-e tanácsadó bevonva a változások menedzselésébe?

\begin{tabular}{lccccccc}
\hline \multirow{2}{*}{ Állítás } & \multicolumn{2}{c}{ Külföldi } & \multicolumn{2}{c}{ Magán } & \multicolumn{2}{c}{ Cégcsoport } & $\begin{array}{c}\text { Ösz- } \\
\text { szes }\end{array}$ \\
\cline { 2 - 8 } & nem & igen & nem & igen & nem & igen \\
\hline$N$ & 77 & 28 & 26 & 73 & 61 & 42 & 105 \\
\hline igen & 26 & 16 & 7 & 35 & 19 & 23 & 42 \\
nem & 51 & 12 & 19 & 38 & 42 & 19 & 63 \\
\hline$\chi^{2}$ & $4,68^{* *}$ & \multicolumn{2}{c}{$3,47^{*}$} & $5,74 * *$ & \\
\hline
\end{tabular}

Ha igen, mi volt a szerepe? (mindkettót megjelölhették)

\begin{tabular}{llllllll}
\hline Szakértő & 13 & 4 & 4 & 13 & 8 & 9 & 17
\end{tabular}

\begin{tabular}{llllllll}
$\chi^{2}$ & \multicolumn{2}{c}{2,54} & \multicolumn{5}{c}{0,21} \\
\hline Támogató & 16 & 13 & 4 & 13 & 10 & 19 & 29
\end{tabular}
$\begin{array}{llll}\chi^{2} & - & - & 3,57 *\end{array}$

Ha a $\chi^{2}$ próba nem végezhető el az alacsony jelölésszám miatt, azt gondolatjellel jeleztük. " $10 \%$-on szignifikáns, ${ }^{* *} 5 \%$-on szignifikáns, ${ }^{* * *} 1 \%$-on szignifikáns.

A megkérdezett szervezetek többsége nem vont be tanácsadót a változások menedzselésébe (5. táblázat). Valószínúsíthető (5\%-os szignifikanciaszinten), hogy a döntően külföldi tulajdonú, illetve a cégcsoporthoz tartozó szervezetek hajlamosabbak tanácsadókat bevonni. A magántulajdon döntő aránya esetén ugyanez 10\%-os 
szignifikncia mellett igaz. A tanácsadó szakértőként vagy támogatóként játszott szerepe és a tulajdonosi jellemzók között csak 10\%-os szignifikanciaszinten találtunk összefüggést: a szakértői szerep jellemzőbb a hazai, mint a külföldi tulajdonú szervezetekre, a támogató szerep pedig a cégcsoporthoz tartozókra az ilyenhez nem kötődőkhöz viszonyítva.

Rákérdeztünk arra is, hogy a változási folyamat különböző szakaszaiban, akcióiban, beavatkozásaiban kik vettek részt a szervezet belső érintettjei és az esetlegesen alkalmazott tanácsadók közül (felsố vezetốk (FV), középvezetôk (KV), alkalmazottak (A), tanácsadók (T)), ami egyben arra is utal, hogy milyen kiterjedt volt a részvétel. A bevonás mértékéből következtethetünk a változásmenedzselés módjára és az ellenállás erősségére. A következők szakaszok esetében kellett megjelölni az egyes érintettek részvételét (zárójelben az összes jelölés):

Arányait tekintve hogyan ítélik meg az alkalmazottak hozzáállását a változásokhoz?

6. táblázat

\begin{tabular}{|c|c|c|c|c|c|c|c|c|}
\hline \multirow[t]{2}{*}{ Attitúd } & \multirow[t]{2}{*}{ Mutató } & \multicolumn{2}{|c|}{ Döntóen külföldi } & \multicolumn{2}{|c|}{ Döntóen magán } & \multicolumn{2}{|c|}{ Cégcsoport tagja } & \multirow[t]{2}{*}{ Összes } \\
\hline & & nem & igen & nem & igen & nem & igen & \\
\hline \multirow{3}{*}{$\begin{array}{l}\text { Erős érzelmi elkötelezettség } \\
\text { a változások iránt }\end{array}$} & átlag & 22,57 & 19,82 & 14,75 & 24,17 & 24,92 & 17,62 & 21,81 \\
\hline & szórás & 24,00 & 18,78 & 19,02 & 23,67 & 23,90 & 20,52 & 22,63 \\
\hline & $\begin{array}{l}N \\
t\end{array}$ & $\begin{array}{l}74 \\
0.54\end{array}$ & 28 & $\begin{array}{l}24 \\
-177\end{array}$ & 72 & $\begin{array}{l}59 \\
160\end{array}$ & 42 & 102 \\
\hline \multirow{4}{*}{ Hajlandó az aktív részvételre } & átlag & 38,80 & 33,71 & 42,88 & 35,64 & 37,61 & 37,52 & 37,40 \\
\hline & szórás & 27,99 & 23,62 & 32,94 & 25,03 & 26,74 & 27,50 & 26,84 \\
\hline & & 74 & & 24 & 72 & 59 & & \\
\hline & $\mathrm{t}$ & 0,85 & & 0,99 & & 0,02 & & \\
\hline \multirow{3}{*}{$\begin{array}{l}\text { Szóban támogató, } \\
\text { de nem aktív }\end{array}$} & átlag & 11,40 & 13,46 & 10,33 & 12,44 & 11,63 & 12,37 & 11,97 \\
\hline & szórás & 12,35 & 13,01 & 11,23 & 13,03 & 11,52 & 14,03 & 12,50 \\
\hline & & $\begin{array}{l}74 \\
-074\end{array}$ & & $\begin{array}{l}24 \\
-071\end{array}$ & & 59 & & 102 \\
\hline \multirow{4}{*}{ Semleges hozzáállás } & átlag & 18,90 & 14,79 & 20,33 & 16,77 & 18,78 & 15,58 & 17,77 \\
\hline & szórás & 21,18 & 12,20 & 23,78 & 17,53 & 22,07 & 13,58 & 19,17 \\
\hline & & 74 & & 24 & & 59 & & \\
\hline & t & 1,22 & & & & 0,90 & & \\
\hline \multirow{3}{*}{ Passzív ellenállás } & átlag & 4,94 & 12,11 & 8,48 & 6,24 & 4,63 & 10,40 & 6,93 \\
\hline & szórás & 11,27 & 15,41 & 18,12 & 10,09 & 11,91 & 13,70 & 12,88 \\
\hline & & 73 & & 23 & & 59 & & \\
\hline \multirow{4}{*}{ Aktív ellenállás } & tátlag & & & $\frac{0,15}{350}$ & & $\frac{\mid-2,24 \cdots w}{173}$ & & \\
\hline & autárás & $\mid \begin{array}{l}2,03 \\
672\end{array}$ & 4,50 & 还 & 3,122 & $\begin{array}{l}1, / 3 \\
478\end{array}$ & $\begin{array}{l}4,91 \\
747\end{array}$ & {$\left[\begin{array}{l}3,02 \\
610\end{array}\right.$} \\
\hline & & 74 & 28 & 24 & 72 & 59 & 42 & 102 \\
\hline & $t$ & $-0,98$ & & 0,26 & & $-2,43 * *$ & & \\
\hline \multirow{4}{*}{ Agresszív ellenállás } & átlag & 0,81 & 1,04 & ,08 & 1,21 & 0,71 & 1,12 & 0,87 \\
\hline & szórás & 3,77 & 2,38 &, 41 & 4,04 & 3,99 & 2,54 & 3,44 \\
\hline & & 74 & 28 & & 72 & 59 & 42 & 102 \\
\hline & $\mathrm{t}$ & $-0,29$ & & $-2,33 * *$ & & $-0,59$ & & \\
\hline \multirow{4}{*}{ Aktív támogató } & átlag & 61,36 & 53,54 & 57,63 & 59,81 & 62,53 & 55,14 & 59,22 \\
\hline & szórás & 31,17 & 28,17 & 32,81 & 29,85 & 30,82 & 29,86 & 30,44 \\
\hline & & 74 & 28 & 24 & |72 & 59 & 42 & 102 \\
\hline & $\mathrm{t}$ & 1,16 & & $-0,30$ & & 1,20 & & \\
\hline \multirow{4}{*}{ Támogató } & átlag & 72,76 & 67,00 & 67,96 & 72,24 & 74,15 & 67,51 & 71,18 \\
\hline & szórás & 27,18 & 25,79 & 30,48 & 26,01 & 26,94 & 26,57 & 26,80 \\
\hline & & 74 & 28 & 24 & |72 & 59 & 42 & 102 \\
\hline & $\mathrm{t}$ & 0,97 & & $-0,67$ & & 1,23 & & \\
\hline \multirow{3}{*}{ Ellenálló } & & 8,45 & & 12,22 & & 7,07 & & 10,86 \\
\hline & szórás & 16,93 & 17,51 & 24,44 & 14,64 & 16,64 & 17,38 & 17,45 \\
\hline & $\begin{array}{l}N \\
t\end{array}$ & $\begin{array}{l}73 \\
-2,29 * *\end{array}$ & & \begin{tabular}{|l}
23 \\
0,39
\end{tabular} & 172 & $\begin{array}{l}59 \\
-2,76 * * *\end{array}$ & & 101 \\
\hline
\end{tabular}


- a változás szükségességének felismerése (FV: 100, KV: 17, A: 3, T: 12),

- a probléma meghatározása, diagnosztizálása (FV: 80, KV: 46, A: 10, T: 32),

- az elérendő cél meghatározása (FV: 100, KV: 36, A: 3, T: 18),

- a szükséges beavatkozások megtervezése (FV: 84, KV: 67, A: 10, T: 27),

- a beavatkozások megvalósítása (FV: 61, KV: 82, A: 59, T: 10),

- visszajelzés a beavatkozásokról (FV: 40, KV: 79, A: 65, T: 6).

$\mathrm{Az}$ adatok a felső vezetők változásmenedzselésben betöltött kiemelt szerepét mutatják (csak a beavatkozások megvalósítása és a visszajelzés esetében szorultak a második helyre a középvezetők mögé). Szintén megállapítható volt, hogy a tanácsadók és alkalmazottak bevonása a változásokba nem jellemző (kivéve az előbbiek esetében a probléma meghatározását, utóbbiaknál a megvalósítást és a visszajelzést). A tulajdonosi szerkezet hatása az egyes szakaszokba bevont érintettekre elenyészőnek bizonyult. Mindössze a tanácsadókat vonták be az elérendő cél meghatározásába nagyobb arányban a cégcsoporthoz tartozók $(12 / 42=29 \%)$, mint a nem cégcsoport tagok $(6 / 61=10 \%)$ $\left(\chi^{2}=6,05^{* *}\right)$, és a szükséges beavatkozások megtervezésébe a magántulajdonú szervezetek $(24 / 73=33 \%)$ a köztulajdonúakhoz képest $(3 / 26=12 \%)\left(\chi^{2}=4,40^{* *}\right)$.
A következő kérdéskör alapján a szervezeti tagok, alkalmazottak változással kapcsolatos attitúdjét elemezzük (6. táblázat). A válaszadóknak százalékos arányban kellett meghatározniuk, hogy milyen mértékú volt a változás alkalmazotti támogatottsága, illetve az ezzel szembeni alkalmazotti ellenállás. Hét lehetséges hozzáállás között kellett elosztani 100\%-ot, azaz meghatározni, hogy az egyes attitúdök relatíve (a többi attitûdhöz képest) mennyire jellemezték a szervezet alkalmazottait.

A 6. táblázat utolsó 3 attitűdjét az előzőek kombinációjaként alakítottuk ki. A kérdőívben Coetsee (1999) által meghatározott hét változásra adható egyéni reakciót soroltuk fel, de a kis elemszámok miatt az eredmények statisztikailag így nem elemezhetók. Ezért tágabb kategóriákba összevonva is megvizsgáltuk őket. Az első két magatartást (,erős érzelmi elkötelezettség a változások iránt”, „hajlandó az aktív részvételre”) együttesen „aktív támogató”-nak neveztük el (az első két magatartásra adott százalékpontokat összeadva kaptuk meg az értékét), az első három hozzáállást („,erôs érzelmi elkötelezettség a változások iránt”, „hajlandó az aktív részvételre”, ,szóban támogató, de nem aktív”) összevonva jutottunk a „támogató” kategóriához (az „aktív támogató” kategória tehát részét képezi a bővebb „támogató” kategóriának), az „ellenálló” kategóriát pedig a "passzív ellenállás”, az „aktív ellenállás” és az „agresszív ellenállás"-ra adott értékekből képeztük (szin-

\section{Alkalmazták-e az alábbi elemzési módszereket?}

\begin{tabular}{|c|c|c|c|c|c|c|c|}
\hline \multirow{2}{*}{ Módszerek } & \multicolumn{2}{|c|}{ Külföldi } & \multicolumn{2}{|c|}{ Magán } & \multicolumn{2}{|c|}{ Cégcsoport } & \multirow{2}{*}{ Összes } \\
\hline & nem & igen & nem & igen & nem & igen & \\
\hline $\mathrm{N}$ & 77 & 28 & 26 & 73 & 60 & 42 & 104 \\
\hline \multirow{2}{*}{ Kérdőívek } & 11 & 4 & 3 & 11 & 10 & 5 & 15 \\
\hline & \multicolumn{2}{|c|}{-} & \multicolumn{2}{|c|}{ - } & \multicolumn{2}{|c|}{0,45} & \\
\hline \multirow{2}{*}{ Interjúk } & 13 & 7 & 2 & 17 & 12 & 8 & 20 \\
\hline & \multicolumn{2}{|c|}{0,82} & \multicolumn{2}{|c|}{$3,01^{*}$} & \multicolumn{2}{|c|}{0,01} & \\
\hline \multirow{2}{*}{ Munka tanulmányozása } & 35 & 18 & 10 & 41 & 29 & 22 & 53 \\
\hline & \multicolumn{2}{|c|}{$2,72 *$} & \multicolumn{2}{|c|}{2,41} & \multicolumn{2}{|c|}{0,16} & \\
\hline \multirow{2}{*}{ Folyamatok elemzése } & 49 & 26 & 15 & 57 & 37 & 37 & 75 \\
\hline & \multicolumn{2}{|c|}{$8,20 * * *$} & \multicolumn{2}{|c|}{$4,02 * *$} & \multicolumn{2}{|c|}{$8,67 * * *$} & \\
\hline \multirow{2}{*}{ Dokumentumok, számviteli, pénzügyi kimutatások elemzése } & 45 & 19 & 13 & 48 & 36 & 26 & 64 \\
\hline & \multicolumn{2}{|c|}{0,65} & \multicolumn{2}{|c|}{2,01} & \multicolumn{2}{|c|}{0,04} & \\
\hline \multirow{2}{*}{ Csoportos megbeszélések tanácsadó bevonásával } & 19 & 11 & 2 & 28 & 13 & 17 & 30 \\
\hline & \multicolumn{2}{|c|}{2,03} & \multicolumn{2}{|c|}{$8,54 * * *$} & \multicolumn{2}{|c|}{$4,21 * *$} & \\
\hline \multirow{2}{*}{ Csoportos megbeszélések tanácsadó bevonása nélkül } & 51 & 16 & 15 & 48 & 42 & 23 & 67 \\
\hline & \multicolumn{2}{|c|}{0,89} & \multicolumn{2}{|c|}{0,54} & \multicolumn{2}{|c|}{2,48} & \\
\hline
\end{tabular}

A cellák felső sorában a jelölések darabszáma, alattuk a $\chi^{2}$ statisztika található. Ha a próba nem végezhető el az alacsony jelölésszám miatt, azt gondolatjellel jeleztük. *10\%-on szignifikáns, ${ }^{* * *} 1 \%$-on szignifikáns. 
tén a százalékpontok összeadásával). Néhány esetben szignifikáns különbséget találunk e kategóriákban az egyes tulajdonlási változók mentén. A külföldi és a cégcsoporthoz tartozó vállalatok esetében jelentósen magasabb az „ellenállás” attitúdje és ezen belül mindkét csoportnál a „passzív ellenállás”-é is, kizárólag a cégcsoportok esetén pedig az „aktív ellenállás” magasabb átlagértéke is kimutatható. A magántulajdonú szervezetek esetében magasabbnak mutatkozik az „agresszív ellenállás", mint a közszférában. Mintánk alapján tehát úgy tűnik, van köze a tulajdonosi szerkezetnek az alkalmazottak változásokhoz való hozzáállásához, még pontosabban az azokkal szembeni ellenállásuk mértékéhez: erósebbnek észlelik az ellenállást, ha a szervezet külföldi tulajdonú és/vagy cégcsoport részét alkotja, és kevésbé agresszívnak, ha a közszférához tartozik.

$\mathrm{Az}$ szervezetek által alkalmazott helyzetelemzési módszerekből is lehet következtetni a változásmenedzselési módra (7. táblázat), hiszen a szervezetfejlesztésre az erős részvétel jellemző, és ezek megvalósításához tipikusan társul a kérdőíves módszer, az interjúk vagy a csoportos megbeszélések alkalmazása (Brown, 2011). Ezért arra is kíváncsik voltunk, ezekre vonatkozóan találunk-e tulajdonosi szerkezet szerinti eltéréseket.

A leggyakrabban megjelölt elemzési módok közül a folyamatelemzés, a dokumentumelemzés, a munka tanulmányozása a formális területek vizsgálatára enged következtetni, és ezek a módszerek kisebb mértékú dolgozói részvétellel történnek. Csupán 15 válaszadó jelölte meg a kérdő́ivek, és 20 az interjúk alkalmazását, melyek a magatartás-tudományi szervezetfejlesztés jellemző diagnosztizáló módszerei. Egyedül a „csoportos megbeszélések tanácsadó bevonása nélküll" (67 válasz) jelenthet szélesebb körú alkalmazotti részvételt, bár a kérdőívünkből nem derült ki a megbeszélések témája, sem a bevontak köre.

A statisztikai elemzésekből látható, hogy csak kevés elemzési módszer esetében lehetett kimutatni öszszefüggést a tulajdonosi szerkezet három vizsgált dimenziójával: a folyamatelemzést a külföldi, illetve a magántulajdonú és a cégcsoporthoz tartozó, a tanácsadóval folytatott csoportos megbeszéléseket pedig a magántulajdonú és a cégcsoporthoz tartozó szervezetek statisztikailag is jelentősen gyakrabban alkalmazzák, mint a komplementer csoportokhoz tartozó vállalatok. A cégcsoporthoz és a magánszférához tartozók tehát ugyanazon - két eszköz alkalmazására is nagyobb hajlamot mutattak mintánkban.

\section{Konklúzió}

Cikkünk a tulajdonosi szerkezet három jellemzőjének (hazai vagy külföldi tulajdon, magán- vagy köztulajdon, cégcsoporthoz tartozás) és a szervezetek változás- menedzselési gyakorlatának összefüggéseit vizsgálta egy nem reprezentatív kérdőíves adatfelvétel eredményeire támaszkodva. Bár a minta a válaszok megoszlásainak általánosítását nem tette lehetôvé, a változók (az egyes menedzsmentjellemzők és tulajdonosi szerkezet három vizsgált dimenziója) közti kapcsolatok feltárására korlátozottan ugyan, de megfelelố volt.

Az szakirodalmi áttekintés és saját kutatásunk is mutatja a szervezeti változások sokszínúségét, komplexitását, azt, hogy számtalan kiváltó oka és tárgya lehet a változásoknak, s menedzselésükre sincs egyetlen tökéletes megoldás. Az általunk feldolgozott szakirodalom viszont csak áttételesen mutat releváns összehasonlítási alapot konkrét vizsgálati eredményeinkkel. A tulajdonosi szerkezet és a változásmenedzsment jellemzői közt meglévő összefüggéseket vizsgáló kutatást nem találtunk. A közszféra szervezeteire vonatkozó megállapításokat Senior és Swailes (2010) fogalmaz meg: a szervezetfejlesztés nehezen összeegyeztethető a közszféra struktúráival és kultúrájával. McConkie (1993) ennek okait is számba veszi. Egyes tanulmányok a nonprofit szervezetek változásmenedzselési sajátosságait tekintik át (például Farkas, 2005), mások egy-egy kiemelt szektorra koncentrálnak (mint Farkas, 2015). Kutatásunk ezért feltáró jellegú volt, konkrét elméleti modellt vagy máshol talált empirikus összefüggéseket tesztelni nem tudtunk.

Talán a legfontosabb tapasztalatunk, hogy annak ellenére, hogy a tulajdonosi szerkezet és más szervezeti jellemzők közt a szakirodalom mutatott ki releváns öszszefüggést, mi a vizsgált egyes részkérdések esetében sokszor nem azonosítottunk jelentós összefüggést a tulajdonosi szerkezettel, vagy az összefüggés csak 10\%os szinten volt szignifikáns.

- A hazai, illetve külföldi tulajdon és a cégcsoporthoz tartozás nem állt jelentős összefüggésben a változások előtt tapasztalat jelenségekkel.

- A magán és külföldi tulajdon, valamint a cégcsoporthoz tartozás nem függött jelentősen össze azzal, hogy mire gyakorolt hatást a szervezeten belül a változás.

- A változás mértékében nem találtunk különbséget a válaszadó között.

- A különböző szereplôk bevonásának kiterjedtsége nem függött össze a tulajdonos(ok) hazai vagy külföldi voltával, és a másik két tulajdonlási jellemzővel is csak egy-egy esetben.

Néhány esetben azonban statisztikailag is alátámasztható (5\%-on szignifikáns) különbséget tapasztaltunk a válaszokban a tulajdonosi szerkezet jellemzói alapján. Ezeket az utóbbiak szerint csoportosítva mutatjuk be. 
A többségében külföldi tulajdonú szervezetek esetében (a többségében hazaiakhoz képest):

- többször gyakorolt hatást a lezajlott változás a rendszerekre,

- kevesebbszer követtek reaktív, és többször követtek pre-, illetve proaktív alkalmazkodási stratégiát,

- többször vontak be tanácsadót a változások menedzselésébe,

- az alkalmazottakat jobban jellemezte az ellenállás és ezen belül a passzív ellenállás,

- többször alkalmazták a folyamatok elemzését.

A többségében köztulajdonban lévő szervezetek a többségében magántulajdonban lévőkhöz képest:

- többször tapasztaltak a változásokat megelőzően jogszabályváltozást,

- ritkábban a válságot, a piaci verseny erősödését, a piaci igény változását és az új technológiai lehetőségeket,

- többször jellemezte óket reaktív, és ritkábban preaktív alkalmazkodás, ritkábban jellemezte az alkalmazottaikat agresszív ellenállás,

- kevesebbszer alkalmaztak folyamatelemzést és csoportos megbeszéléseket tanácsadó bevonásával.

A cégcsoporthoz tartozó szervezetek a cégcsoporthoz nem tartozókhoz képest szignifikánsan:

- többször vontak be tanácsadót a változások menedzselésébe,

- többször vonták be esetlegesen alkalmazott tanácsadóikat az elérendő célok meghatározásába,

- a változásokkal szemben inkább jellemezték alkalmazottaikat ellenállást tanúsítónak (ezen belül mind passzívan, mind aktívan ellenállóbbnak is),

- többször alkalmazták a folyamatok elemzését,

- többször alkalmaztak csoportos megbeszéléseket tanácsadó bevonásával.

Azokban az esetekben, amikor csak 10\%-os szignifikancia mellett találtunk kapcsolatot a tulajdonlás és a változásmenedzsment közt (ezek a fenti felsorolásokban nem szerepelnek), újabb vizsgálatok tisztázhatják ezek tényleges meglétét.

Fontos megjegyezni, hogy ahol mutattunk is ki öszszefüggéseket a tulajdonosi szerkezet és a változásmenedzsment jellemzői közt, ezeket egyrészt nem tekinthetjük az előbbi utóbbiakra gyakorolt hatásának, mivel az okozatiság megállapításához az adataink nem voltak elegendőek, másrészt pedig - mivel nem reprezentatív mintán dolgoztunk - nem tudjuk, mennyire terjeszthetôk ki az eredményeink, ezt csak újabb vizsgálatok, és az azok eredményeivel való összevetés világíthatja meg. Ugyanakkor a kimutatott kapcsolatok esetében mindenképpen elegendóek az eredmények ahhoz, hogy ezen összefüggések létét igazolják: a kérdés most már ezek elterjedtsége a teljes sokaságban.

\section{Felhasznált irodalom}

Ackoff, R. (1981): Creating the Corporate Future: Plan or be Planned. New York: John Wiley

Ansoff, I. H. - McDonnell, E. J. (1990): Implanting Strategic Management. Englewood Cliffs, NJ: Prentice Hall

Babbie, E. (2012): The Practice of Social Science Research. 13th edition, International edition, Wadsworth, OH: Cengage Learning

Bakacsi, Gy. (2015): A szervezeti magatartás alapjai. Alaptankönyv bachelor hallgatók számára. Budapest: Semmelweis Kiadó

Balaton K. (2009): AZ EU-csatlakozás óta bekövetkezett változások és azok hatása a vállalati stratégiákra - Összefoglaló az interjúk tapasztalatairól. Múhelytanulmány 55. Budapest: Budapesti Corvinus Egyetem, Vállalatgazdaságtan Intézet, Versenyképesség Kutatóközpont

Beer, M. - Eisenstat, R. A. - Spector, B. (1990): The Critical Path to Corporate Renewal. Boston, MA: Harvard Business School Press

Benn, S. - Dunphy, D. - Griffiths, A. (2006): Enabling Change for Corporate Sustainability: An Integrated Perspective. Australasian Journal of Environmental Management; Vol. 13, September, p. 156-165.

Brown, D. R. (2011): An Experimental Approach to Organizational Development. Eighth edition. Upper Sadle River, NJ: Pearson Education Inc.

Burke, W. W. - Litwin, G. H. (1992): A Causal Model of Organizational Performance and Change. Journal of Management. Vol. 18, No. 3., p. 523-545.

Burnes, B. (2009): Managing Change: A Strategic Approach to Oeganizational Dynamics. Fifth Edition, Harlow: Pearson Education Limited

Coetsee, L. (1999): From Resistance to Commitment. Public Administration Quarterly, Vol. 23, No. 2, p. 204-222.

Dobák M. (2008): Szervezeti formák és vezetés. Budapest: Akadémia Kiadó

Dunphy, D. - Stace, D. (1993): The Strategic Management of Corporate Change. Human Relations, Vol. 46, No. 8., p. 905-920.

Farkas F. (2005): Változásmenedzsment. Budapest: Akadémiai Kiadó

Farkas F. (2015): A szervezeti változások természete - a pénzintézeti szektor példái. in: Bakacsi Gyula - Balaton Károly (szerk.): Vezetés és szervezet tár- 
sadalmi kontextusban: Tanulmányok Dobák Miklós 60. születésnapja tiszteletére. Budapest: Akadémiai Kiadó, p. 143-160.

French, W. L. - Bell, C. H. (1995): Organizational Development, Behavioral Science Interventions for Organization Improvement. Fifth edition, Englewood Cliffs, NJ: Prentice Hall

Fülöp Gy. (2008): Stratégiai menedzsment. Elmélet és gyakorlat. Budapest: Perfekt Kiadó

Grundy, T. (1993): Managing Strategic Change. London: Kogan Page

Kübler-Ross, E. (1988): A halál és a hozzá vezető út. Budapest: Gondolat Kiadó

McConkie, M. L. (1993): Organization Development in the Public Sector. in: Cummings, T. G. - Worley, C. G. (1993): Organization Development and Change. Fifth edition, St. Paul, MN; West

Plowman, D. A. - Baker, I. T. - Beck, T. E. - Kulkani, M. - Solansky, S. T. - Travis, D. V. (2007): Radical Change Accidentally: the emergence and amplification of small change. Academy of Management Journal, Vol. 50, No. 3, p. 515-543.

Pulinka, Á. (2016): A szervezeti változással szembeni ellenállás, mint természetes és szükségszerú gyászfolyamat. Vezetéstudomány, Vol. 47, No. 6, p. 41-51.

Robbins, S. P. - Judge, T. A. (2013): Organizational Behavior. Fifteenth edition, Upper Saddle River, N.J.: Pearson Prentice Hall
Saunders, M. - Lewis, P. - Thornhill, A. (2016): Research Methods for Business Students. 7th edition, Harlow: Pearson

Schlesinger, P. F. - Sathe, V. - Schlesinger, L. A. Kotter, J. P. (1992): Organization. Text, Cases, and Readings on the Management of Organizational Design and Change. Third edition, Boston, MA: Irwin

Senior, B. - Swailes, S. (2010): Organizational Change. Fourth Edition, Harlow: Pearson Education Limited

Spector, B. (2013): Implementing Organizational Change, Theory into Practice. Third Edition, London: Prentice Hall

Szabó Zs. R. (2005): A stratégiaalkotás folyamata. Múhelytanulmány 15. Budapest: Budapesti Corvinus Egyetem, Vállalatgazdaságtan Intézet, Versenyképesség Kutatóközpont

Ujhelyi M. - Kun A. I. (2016): Szervezeti változásokat kiváltó tényezők empirikus vizsgálata. Taylor: Gazdálkodás- és Szervezéstudományi Folyóirat: A Virtuális Intézet Közép-Európa Kutatására Közleményei, Vol. 8, No. 2, p. 36-43.

Viardot, E. - Calderon-Moncloa, L. F. (2011): The Impact of National Culture on Change Management: A Latino American Illustration. Journal of International Management Studies, Vol. 11, No. 1, p. 32-42.

A cikk beérkezett: 2016. január Lektorálás után elfogadva: 2016. december 